\title{
Bolaño against Babel: Multilingualism, Translation and Narration in 2666, 'La parte de los críticos'
}

\author{
TILMANN ALTENBERG
}

Cardiff University

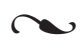

\begin{abstract}
This article examines the first part of Roberto Bolaño's novel 2666 with regard to the strategy of telling a multilingual story in a monolingual narrative. Discussing the motives behind, and implications of, this flattening of the text's linguistic surface, it argues that to dismiss the tension between story and discourse as a defect is to overlook one of the novel's principal proposals and to deny a key aspect of Bolaño's narrative poetics. The article shows that in 'La parte de los criticos', effortless communication is confined to a utopian communicative space, which provides a level playing field for characters from different cultural-linguistic backgrounds. The novel's approach to multilingualism and translation, for which Bolaño may have found support in his readings of Ludwig Wittgenstein, suggests that to him, languages matter not for what separates them but for what they have in common as a generic means of communication. The article contends that the novel's linguistic flatness is programmatic, exposing to ridicule narratives that claim to represent reality faithfully. In place of the myriad real-world problems of Babel, Bolaño sets an ideal of linguistic transparency and perfect translatability made possible by way of literature.
\end{abstract}

\section{Resumen}

Este artículo examina la primera parte de la novela 2666, de Roberto Bolaño, con respecto a la estrategia de contar una historia plurilingüe en un relato monolingüe. Analizando los motivos detrás de esta nivelación de la superficie lingüística, así como las implicaciones de ella, argumenta que descartar la tensión entre historia y discurso como un defecto es pasar por alto una de las principales propuestas de 2666 y negar un aspecto clave de la poética narrativa de Bolaño. El artículo demuestra que, en 'La parte de los críticos', la comunicación fluida existe únicamente dentro de un espacio comunicativo utópico, que ofrece igualdad de condiciones para personajes de trasfondos lingüístico-culturales distintos. El particular enfoque de la novela sobre el plurilingualismo y la traducción, para el que Bolaño puede haberse inspirado en Ludwig Wittgenstein, sugiere que a aquel escritor las lenguas le importan no por lo que las separa sino por lo que tienen en común 
en cuanto medio de comunicación genérico (lenguaje). El artículo sostiene que el monolingüismo de la novela es programático, poniendo en ridículo narraciones que afirman representar la realidad fielmente. En lugar de los múltiples problemas reales de Babel, Bolaño propone el ideal de una transparencia lingüística y traducibilidad perfecta hechas posibles a través de la literatura.

Critics of Roberto Bolaño's prose have remarked - not always favourably - on its relative simplicity and accessibility, which, in the words of Alberto Medina, make it 'readable for everyone just interested in good stories that don't last for too long' (2009: 549). ${ }^{1}$ Discussing Los detectives salvajes, Medina further observes a 'tension between the subject and the formal strategies' (551), which applies also to 2666 , in particular to the novel's first part, 'La parte de los críticos', where the linguistic plurality at the story level is at odds with its narrative presentation. In this article, I subject the first part of 2666 to a close examination of the strategies employed in conflating the multilingual story into a monolingual narrative, trying to expose the motives behind, and implications of, this flattening of the linguistic surface. In doing so, I will first explore how the languages spoken at the story level are organized relative to each other and to the language in which the novel is written, in order to then examine the ways in which the narrator renders speech events in the different languages involved. This will lead me to a discussion of the text's proposal regarding linguistic diversity, verbal communication and translation. The article will argue that to dismiss the tension between multilingualism at the story level and monolingualism at the discourse level as a defect of the novel is to pass over one of 2666's principal proposals and to deny a key aspect of Bolaño's narrative poetics.

Not unlike US-American mainstream cinema, which tends to 'ignore or deny issues of language difference' (Dwyer 2005: 297), in Bolaño's 'maximalist novel' (Ercolino 2014) there is a mismatch between the story's (mostly implicit) multilingualism and the narration's strict Spanish monolingualism, which extends to the discourse of both the narrator and the characters. As Randolph D. Pope notes, 'While supposedly in this novel we should hear Spanish, English, French, German, and even Russian, there is nothing but Spanish, as if the final barrier (or Berlin/ Babel Wall) had completely collapsed' (2011: 160). This representation of multilingualism adheres largely to what Meir Sternberg, in a seminal article, has called the 'homogenising convention', which consists in 'standardising the imitating medium' (1981: 224). While, in principle, this phenomenon can also be found in other texts by Bolaño - for example, in Los detectives salvajes (1998), El

1 This view echoes opinions expressed by, for example, Javier Cercas, who calls Bolaño 'un narrador compulsivamente legible, inmediatamente cordial, arrebatadoramente atractivo', linking the legibility and narrativity of Bolaño's prose to 'una cierta corriente dominante en la narrativa seria escrita en castellano en los últimos años' (2007: n. p.). Carlos Cuevas Guerrero, on the other hand, remarks upon Bolaño's 'exceso de legibilidad' as a danger (2006: n. p.). Colombian writer Darío Jaramillo goes even further, openly declaring his dislike of Bolaño's prose and denouncing it as stylistically limited and excessively repetitive: '[Bolaño] [t]iene pocos recursos y los repite sin variar' (2007: n. p.). 
Tercer Reich (2010) and, to a lesser extent, La literatura nazi en América (1996) - the prominence and consistency of the mismatch in 'La parte de los críticos' make this part of the novel stand out both from the other texts and from the rest of 2666 .

As we will see, Bolaño is not oblivious to the implications of the complex linguistic situation in this part of his novel; rather, he proposes a communicative space within which there are no such implications. Language, interlingual communication and translation are not foregrounded because in the novel they are, for the most part, unproblematic (see Pope 2011: 160). In creating a level playing field for his main characters, who appear to be speaking a single generically conceived language, rather than individual tongues, Bolaño's narrator shifts focus to the more subtle pitfalls of intralingual communication. It is on this level of a 'Eurotopian'2 communicative space of interlingual transparency, possible only in literature, where the narrator's authority and acute linguistic awareness come into their own, leaving us with a delightfully complex, yet accessible, narrative. The novel's approach to multilingualism and translation, for which Bolaño may have found support in his readings of Ludwig Wittgenstein, suggests that, to him, languages matter not for what separates them but for what they have in common as a generic means of communication. It will become apparent that ultimately the novel's linguistic flatness is as much programmatic as it is a manifestation of Bolaño's dislike for narratives that aim to create the illusion of representing the world faithfully.

2666 has attracted much critical attention for its unflinching portrayal of the series of brutal crimes against women in the fictitious Mexican city of Santa Teresa, modelled after the infamous border town Ciudad Juárez. Perhaps due to its disproportionate length (352 pages in the original Spanish edition) and the disturbing cumulative effect of the countless detailed descriptions of the murder victims, 'La parte de los crímenes' is often considered the novel's epicentre (see, most recently, Sharae Deckard (2012), Sarah Pollack (2013: 662), Annabel Patterson (2014) and Arndt Lainck (2014)). The other four parts have been studied primarily with regard to their contribution to this assumed main focus and overarching concern. Such thematically induced macro-perspectives tend, however, to overlook the novel's specific linguistic and narrative makeup, overemphasizing the unifying elements of Bolaño's magnus opus across its rather diverse parts. It is also worth keeping in mind Bolaño's instructions for the manuscript to 'be published as five separate tomes' (Levinson 2009: 177). Although widely dismissed as ill-conceived and indicative of practical rather than aesthetic concerns (see, e.g., Echevarría, 2004: 1121), Bolaño's instructions do suggest that the novel's five parts not only 'toleran una lectura independiente', as the first editor, Ignacio Echevarría concedes somewhat begrudgingly (2004: 1122), but that each merits being read, and studied, in its own right.

2 I have coined the term 'Eurotopia' for the (utopian) idea of a homogeneous culturallinguistic space within the confines of Europe. 
In 'La parte de los críticos', which spans nearly 200 of the 1,100 pages of the original Spanish-language edition, we are introduced to four academics, ${ }^{3}$ from different European countries, who have specialized in the work of the German prose writer Benno von Archimboldi. Their obsession with the elusive author forms the basis of a friendship which soon extends beyond the European conference scene that has initially brought the four together. The meandering story of this part of the novel, set in the mid- to late 1990s, is sustained by two intertwined strands: first, the Germanists' desire to meet Archimboldi in person, which leads them to engage in a rather desperate - and, ultimately, failed attempt to track him down in Mexico; ${ }^{4}$ second, the shifting intimate relationship between the only female academic involved and her three male friends. Being from Spain, France, Italy and England, respectively, none is a native speaker of German. Their linguistic competencies are rather mixed. In addition to their native tongue, all four speak German as their language of professional specialization. The story, therefore, involves the five most spoken mother tongues in the current European context, ${ }^{5}$ the same languages that arguably represent the core of the (Western) European cultural heritage of the modern era, as well as Bolaño's personal preferences as a reader. Evidence of the latter can be found, for example, by looking at the authors and texts discussed or referred to in Bolaño's posthumous collection of articles and speeches Entre paréntesis (Bolaño 2004b). Italian, English, French and German (in this order) were also the first languages to see translations of 2666 . $^{6}$

Given the critics' multilingual competency and the ease with which they move about the European conference scene, they embody a generation of cosmopolitan academics in their early thirties to early forties in a globalized world. This line-up of characters from different cultural and linguistic backgrounds, who are language professionals and can therefore be assumed to be fully aware of the difficulties involved in communication and translation across cultural and linguistic boundaries, opens up ample space for experiences of difference. One might, therefore, expect language, communication and translation to surface as topics in the characters' many conversations and reflections. Bolaño might further be expected to use the multilingualism at the story level to show the reader instances of linguistic barriers and resulting miscommunication in the friends' frequent verbal interactions. And finally, given their different first

3 In the English translation of the novel, 'críticos' is rendered as 'critics'; as academics in the field of German literature, they might for clarity be better termed Germanists, linguists or simply academics.

4 Ignacio Rodríguez de Arce even refers to 'La parte de los críticos' as 'el relato de un fracaso' (2006: 204).

5 According to a recent report by the European Commission, which largely reproduces earlier findings, these are, in descending order, German (16 per cent of the population of the member states of the EU), Italian and English (13 per cent each), French (12 per cent) and Spanish (8 per cent), with Polish also accounting for 8 per cent (2012: 10).

6 Russian, the one language from the list of Bolaño's readings (always in translation) that does not figure in the novel's first part, forms the background of a significant portion of the concluding 'La parte de Archimboldi', where we also find references to Russian writers. 
languages, would it not seem obvious to find in the novel not only indirect traces of their specific linguistic background but also some indication of what language they are speaking at any given moment?

Bolaño largely undermines these expectations, which is one reason that Raúl Zurita (2008) considers 2666 a conventional, minor novel, as Pope (2011: 160) has observed. In open contrast to Zurita's view, Pope defends the novel's linguistic flatness by linking it to a 'cosmopolitan culture' (2011: 160), without looking further into its implications. To Pope, 'this intermingling and travelling, these meldings and confluences [in 2666] are part of the attraction of Bolaño's world, marginless, accessible and uprooted' (161). Against Zurita's assessment, and seeking to expand on Pope's plot-centred defence of 2666, I will argue that the novel constructs multilingualism in such a way that the difficulties and frictions that the reader might expect are not so much avoided or overlooked, as Zurita claims, but effectively denied and deflected.

In our direct experience of real-world communication, every speech act is realized in a specific language. A speaker's choice of language decides whether or not the interlocutors' specific linguistic competency allows them to follow a conversation and engage in it. As readers of fiction, on the other hand, we are removed from any such direct experience of the use of language. More precisely, in fiction the use of a specific language is not necessarily indicative of a character's cultural-linguistic identity or even linked to his or her linguistic competency; put even more bluntly, the language an author chooses to write in need not at all be motivated by the story told. The history of literature is full of narratives about people and locations linguistically and culturally removed from the target readership but that are written in a language accessible to that readership. One need only think of Charles Dickens's Tale of Two Cities (1859), the novels of Karl May (1842-1912) and B. Traven (?1882-?1969) or, to move closer in time and focus in on the Hispanic context, Jorge Volpi's En busca de Klingsor (1999) and Andrés Neuman's El viajero del siglo (2009), to name but a few randomly chosen examples. Such texts appeal to their primary readership in large part because they provide a window on foreign cultures and distant lands, which are often also removed in time, however distorted the view through this window may be. Although such texts are not translations in the linguistic sense of the term, they purport to translate culture. In many cases they also presume acts of linguistic translation of the characters' (imaginary) instances of language use; this is consistently the case in 'La parte de los críticos' of 2666. In the sense just described, the surface phenomenon of the language used by a writer is effectively decoupled from the language or languages spoken by the characters within the story world.

To reveal how the narrator in Bolaño's novel 'translates' the characters' presumed utterances, we first need to establish how the languages evoked at the story level are organized relative to each other and to the language used in the narration. ${ }^{7}$ Multilingualism in 2666 has two dimensions, which I will refer

7 In mapping the linguistic situation in 2666, I draw on the common distinction between 
to as horizontal and vertical, respectively. It is cumulative over the course of the story, i.e., a consequence of the characters' different first languages and the story's geographical mobility (horizontal multilingualism); and it is also rooted, to varying degrees, in each character's complex linguistic competency, as all of them speak more than one language (vertical multilingualism). The academic circuit in which Bolaño's protagonists move appears to be similarly multilingual. Geographically, however, each of the different linguistic environments in which the story unfolds is portrayed as essentially monolingual. This applies equally to the European conference circuit and the Mexican city of Santa Teresa. It may not be accidental that, in keeping with the other critics, which each represent the main language of their respective country of origin, the Spaniard Manuel Espinoza does not come from one of the bilingual Autonomous Communities but from monolingual Madrid. As a consequence of this simplified linguistic geography, the critics' vertical multilingualism appears in the novel as an elite phenomenon embedded in adjoining monolingual environments.

A closer look at the four academics' linguistic competency reveals that it is organized hierarchically. The only critic said to speak all five languages involved is the Spaniard Espinoza; Frenchman Jean-Claude Pelletier's linguistic competency covers four of the languages, excluding only Spanish; Italian critic Piero Morini, so we are told, speaks German and English in addition to his native language; Liz Norton, finally, is at the bottom of this hierarchy, with only her native English and her professional German, the latter of which the narrator characterizes as ‘correctísimo' (Bolaño 2004a: 27). The Spanish critic's position at the top of this hierarchy of linguistic competencies mirrors the privileged position of Spanish as the language in which the novel is written (discourse language) and of the Hispanic world as the cultural-linguistic context in which the novel's three central parts unfold. Just as the Spaniard's reported linguistic competency incorporates all five European languages involved in the story, on the discourse level these story languages are reduced to just one: Spanish. Although the novel does not begin 'in any one country, [but] in an interconnected and fluid [European] geography', as Pope (2011: 160) remarks (see also Ercolino 2014: 84), the space created is not as 'decentred' as this critic would have it, for neither at the story level nor at the discourse level are the five main languages distributed evenly or randomly, with Bolaño's own language placed at the centre of 2666 in both the story and the narrative discourse. Rather than discarding this arrangement as a mere accident, I read it as a way of pinpointing the novel's linguistic and cultural epicentre, relative to which the other four languages are positioned. As we will see later, this view is confirmed by the special treatment of Spanish (story language) in the narration. In translations of 2666, this centre is much less clear, as the respective discourse language no longer mirrors the privileged position of the Spanish language and the Hispanic world on the story level.

story and discourse, referring to the language presumably spoken on the story level as the story language, whereas the language in which the novel is written will be called discourse language. 
The tension between the discourse language and the story language throughout 'La parte de los críticos' begs the question to what extent the 'translated' Spanish version of a given speech event shows any characteristics of a speaker's particular linguistic background. While Bolaño shows a clear preference for indirect forms of rendering speech events over using direct discourse, the occasional fragments of dialogue and the more frequent indirect discourse in languages other than Spanish are uniformly rendered in the Peninsular standard variety of Spanish and preserve no characteristics of the (presumed or labelled) original language at the story level. For example, Norton turns to her friends several times in direct discourse. All of these instances are rendered in Spanish by using the second person plural, which is not generally found in American Spanish ('Os da miedo' (Bolaño 2004a: 96); 'parad de una puta vez', 'lo vais a matar' (103)); in the long emails sent, with slight variations, to Pelletier and Espinoza after her return from Mexico to Europe, Norton addresses her friends following the same paradigm ('vosotros visteis' (198); 'vosotros' (200); 'sé que vosotros lo comprenderéis' (207)). In all these cases the story language is, by implication, either German or English.

I propose to understand the choice of Peninsular Spanish in these passages not as random or suggestive of a personal preference on Bolaño's part but rather as a reflection, and subtle reinforcement, of the character's Europeanness. In a monolingually Spanish novel spanning the Old World and the New World, I would argue, the contrast between these two spheres is linguistically projected onto the difference between Peninsular Spanish and American Spanish. ${ }^{8}$ As Juan Meneses has shown, the same logic informs the mapping of different varieties of Spanish onto characters from varying linguistic backgrounds in the relatively short third part of 2666, 'La parte de Fate' (2014: 179-80). Here, Mexican speakers' utterances in English (story language) are rendered in Mexican Spanish (discourse language), whereas US-Americans cursing in their mother tongue do so in a deliberately created Spanish translatorese (discourse language), i.e. in a register that resembles an 'unidiomatic rendition of words and expressions that results from mistranslation' (176). On the one hand, these examples demonstrate the consistency of certain textual strategies across different parts of the novel. On the other hand, their function and effect vary significantly in each case. While in 'La parte de Fate' the mapping strategy is employed specifically to create 'intertextual parody that adds to the multiple distinctive layers of meaning that converge in the novel as a whole' (182), within 'La parte de los críticos', it tends to fade into the background as one aspect of Bolaño's approach towards language difference at the story level. ${ }^{9}$

8 The French edition of 2666 (Bolaño 2008: 5) claims (rather naively) that the novel has been translated from Chilean Spanish ('Traduit de l'espagnol (Chili)'), drawing on the author's biography rather than a linguistic assessment of the text.

9 In his thought-provoking article, Levinson declares that in the third part of 2666, 'La parte de Fate', 'Spanish is not spoken' (179). This surprising claim, which rests on the supposition that the English-speaking protagonist is "less a character in, than the "perspective" of, "La parte de Fate"' (179), leads Levinson to a number of involved reflections regarding 
In some of the relatively few passages of 'La parte de los críticos' where story language and discourse language coincide - 'vehicular matching', in Sternberg's terminology (1981: 223-25) - the speech events can be clearly linked to specific varieties of Spanish that correspond to the speaker's linguistic background. Espinoza, for example, is repeatedly shown to use strong language, especially when emotionally agitated ('hija de puta' (Bolaño 2004a: 49); 'jodido hijo de puta' (87); ‘joder' (97); 'coño’ (102)). All of these expressions are commonly (although not exclusively) used in Peninsular Spanish. Similarly, Mexican writer and cultural functionary El Cerdo uses a number of expressions that are specific to Mexican Spanish ('pinches mamones cobardes' (137); 'chingados' (138); 'Híjole' (168)); as does Rebeca, the young woman selling crafts on the market in Santa Teresa ('estuvimos platicando' (184); see also (190)). A Mexican bystander who witnesses Espinoza vomiting in a public toilet comments, ' - Guacaree tranquilo, compadre' (182), using a Mexican colloquialism for 'vomitar', which the Spaniard fails to understand. The Chilean professor Oscar Amalfitano, finally, who is on friendly terms with the four main characters, addresses them using the Spanish American paradigm (ustedes instead of vosotros) ('¿Les gustan los frijoles?’ (177)). These examples show that in this novel written in Spanish, (perhaps unsurprisingly) speech events in that language lend themselves more than those in any other story language to recreating convincing dialogue with dialectal and idiosyncratic features. Unlike the lines presumably uttered in German, English or French, Spanish escapes the homogenizing treatment by the narrator, who merely appears to be quoting rather than having to generate a translation. This preferential treatment confirms the privileged position of Spanish within the novel observed above.

While the characters' linguistic competency in 2666 can be established with relative ease, the language they employ at any given point of the story is, for the most part, difficult to ascertain. How are readers supposed to know what language a character is using in any particular speech event if utterances are indistinctly rendered or summarized in Spanish? Or are they even meant to know? The least ambiguous way of signalling the language spoken at the story level in a monolingual text is by labelling it explicitly (see Sternberg 1981: 231). Although there are scattered instances of such labelling for all five languages concerned, ${ }^{10}$ overall Bolaño's narrator displays a reluctance to tag speech events

language use and translation. Although the mapping strategy in 'La parte de Fate' may be less clear than in the first two parts of the novel, in contrast to Levinson I see no compelling reason why the Spanish-speaking characters would not use their (first) language when communicating with each other.

10 Most of these refer to passages rendered as direct discourse: '[L]a inglesa repetía, en alemán: no hay vuelta atrás' (Bolaño 2004a: 70); 'el Cerdo preguntó, en alemán, si le habían robado algo' (136); 'El alemán del estudiante, sin embargo, no era óptimo, por lo que Espinoza se puso a hablar con él en italiano' (126); 'vieron a una pareja de jóvenes que hablaban en español' (85); 'luego [Norton] dijo buenas noches, Piero, en un inglés muy dulce o que a Morini le pareció insoportablemente dulce’ (144); ‘ -¿En qué consiste su número de ilusionismo? -le preguntó Pelletier en inglés' (176); 'El muchacho había dicho, en francés, nunca se sabrá' (182). All italics are mine. 
as occurring in any particular language, which goes hand in hand with his preference for rendering characters' utterances as indirect discourse or summarizing them. This applies throughout the novel. One might presume that in the near-complete absence of language labels, the context would allow the reader to infer which language or languages are used by the characters in a given speech act. Interestingly, this rarely applies in 'La parte de los críticos', where all main characters speak more than one language. In terms of the story language(s), this part of the novel is inherently unstable. As a consequence of the narrative's focus on the critics' transnational, translinguistic friendship and corresponding mobility, the friends are scarcely shown on their respective home territory where their language choice would need no clarification. The conference circuit and mutual visits take them across Europe in what we could call a communicative bubble within which, in linguistic terms at least, near-perfect understanding seems to rule. Given the critics' specialism and shared obsession with German writer Archimboldi, perhaps the only assumption we can safely make relates to German as their language of choice for communicating with each other and for their conference appearances; on several occasions, the friends can also be seen to communicate in English, perhaps as a chivalrous gesture towards Norton.

In synthesis, while Bolaño places the polyglot critics at the centre of a story involving a variety of countries, languages and intercultural encounters, the linguistic and corresponding cultural complexity created is generally conceived of as unproblematic and harmonious. The strict monolingualism of the narrative discourse can thus be seen as the linguistic manifestation of the ease with which the five main European languages play together in the story world. More generally Bolaño seems to suggest that, within the Western European context, linguistic and cultural differences are negligible to the point of not warranting sustained reflection. It is therefore only consistent that, with few exceptions, Bolaño should abstain from drawing attention to the story language, as that might distract readers from the proposed communicative utopia.

One key episode of 'La parte de los críticos', however, highlights the limits of this harmonious vision of a unified European cultural-linguistic space. About half way into the novel's first part, the ménage à trois between Espinoza, Pelletier and Norton enters a crisis with the appearance of a young Englishman, Alex Pritchard. Troubled by Pritchard's seeming familiarity with Norton and determined to keep the presumed intruder away from their love triangle, the men lose all interest in their academic work. On a visit to their lover in London, the Spaniard and the Frenchman press Norton to clarify her relationship with Pritchard, which leads to a long-winded discussion about jealousy, instigated by excessive drinking over a restaurant dinner. The discussion continues in the taxi on the way home, and this is where the critics' communicative bubble bursts, exposing the intellectual complacency and hypocrisy underpinning the friends' presumed communicative utopia. The Pakistani taxi driver, who cannot but overhear the critics' licentious deliberations in English (story language), is outraged at his passengers' lack of decency. First, he murmurs to himself 'en su 
lengua incomprensible' (Bolaño 2004a: 102), to then openly voice his indignation, presumably in English, insulting both Norton and her friends in unmistakable terms:

dijo que [...] por lo que había escuchado, la mujer aquí presente [...] carecía de decencia y de dignidad, y que en su país eso tenía un nombre, el mismo que se le daba en Londres, qué casualidad, y que ese nombre era el de puta, aunque también era lícito utilizar el nombre de perra o zorra o cerda, y que los señores aquí presentes, señores que no eran ingleses a juzgar por su acento, también tenían un nombre en su país y ese nombre era el de chulos o macarras o macrós o cafiches. (102)

This verbal assault prompts an equally rude counterattack on the male critics' part, which culminates in a violent physical attack on the taxi driver, who is finally abandoned half dead on the pavement.

The verbal abuse directed at the Pakistani man draws on confused stereotypes about an assumed homogeneous (Islamic) Asian culture, alluding to the 1989 fatwa against Salman Rushdie and invoking Western feminist activists: 'esta patada es por Salman Rushdie [...], esta patada es de parte de las feministas de París [...], esta patada es de parte de las feministas de Nueva York [...], esta patada es de parte del fantasma de Valerie Solanas, hijo de mala madre' (103). It is ironic that both parties deliver the insults in English ('lo insultaban en inglés' (103; italics in the original)), which is widely considered the language of international understanding. While English (story language) fulfils this function here on a superficial, purely functional level, the mutual linguistic intelligibility of the verbal exchange contrasts with the hostile attitudes and irreconcilability of views. The narrator's references to the taxi driver's other language ('dijo algo en su lengua' (101); 'su lengua incomprensible' (102)), which clearly falls outside the critics' comfort zone, aligns the cultural divide with a linguistic divide. To call the Pakistani's language incomprehensible is obviously a relative statement issued from the critics' particular Western European perspective. While the violent clash between the liberally minded critics and the taxi driver is to some extent motivated at the story level, it nonetheless exposes the limits of the friends' communicative Eurotopia. This is rooted in an elite multilingualism within the confines of Western European mainstream culture of largely monolingual societies. The encounter with cultural-linguistic diversity beyond these limits triggers an irrational, violent response. Although the taxi episode has no lasting effect on the way Espinoza and Pelletier view themselves and their place in the world, in the course of the story it marks the first in a series of uneasy encounters that culminate in the journey to Mexico, where the critics enter what, to them, is a world of uncertainties (see 172).

To understand Bolaño's proposal regarding language and communication, it is important to realize that the temporary suspension of the Eurotopian space the friends inhabit does not question the existence of such a space. On the contrary, by showing its limits and limitations, Bolaño makes us aware of its very existence; he, therefore, does not ignore or downplay the difficulties involved in communicating across linguistic and cultural boundaries. The communicative 
bubble in which the critics move redefines these boundaries in accordance with historical and macro-cultural affinities, at the same time creating a space that allows Bolaño to shift the focus towards communication that is unaffected by linguistic difference.

Given the multiple languages and varying cultural-linguistic contexts evoked in 'La parte de los críticos' (and beyond), it is remarkable how little bearing these have not only on the narrator's choice of language but also on the way verbal communication is portrayed in the novel. Whatever differences and misunderstandings there are, as far as communication among the critics is concerned, these do not generally arise from cultural and linguistic diversity or language choice nor are they shown to be the consequence of different levels of language competency, issues that are only ever addressed in passing. Rather than any specific language, for the most part the medium of communication between the friends appears to be simply language. On several occasions, however, this generically conceived linguistic medium, in which the friends' eloquence unfolds, loses its transparency, prompting a character or the narrator to reflect upon differences in meaning or understanding. By singling out individual words and examining their adequacy without making reference to the story language, any concerns relating to language choice and cultural-linguistic difference are effectively obliterated.

The linguistic unit under consideration is generally explicitly referred to as 'palabra', 'término' or 'expresión'. For example, in a restaurant in a newly developed area of London, Norton makes a remark the wording of which her Italian critic friend Morini finds unsuitable: 'La voz de Liz Norton ponderaba el barrio y el esfuerzo de la gente que lo estaba reflotando. // Morini pensó que la palabra reflotar no era la indicada' (75). Since it is unclear in what language Norton said these words - certainly not in Spanish - Morini's objection to her choice of the word reflotar is pointless as long as we consider it to apply to a specific language. Similarly, Pelletier is amused by an expression he himself has just used in imagining the impression Norton might have had of him had they met in different circumstances: 'puede [...] que ella me hubiera odiado, que me hubiera encontrado pedante, demasiado frío, arrogante, narcisista, un intelectual excluyente. El término intelectual excluyente le divirtió' (82-83). Given that Frenchman Pelletier's reflections are clearly not referring to the Spanish expression intelectual excluyente, his amusement does not arise from the signifier but from the signified, which, in Bolaño's concept, seems to be a stable reference at least across the languages concerned. When the narrator first introduces Norton and her particular view of life, different values are linked to specific expressions and words: 'La expresión "lograr un fin", aplicada a algo personal, le parecía una trampa llena de mezquindad. A "lograr un fin" anteponía la palabra "vivir" y en raras ocasiones la palabra "felicidad"' $(22) .{ }^{11}$ Again, the narrator shows no

11 Reviewing the different examples, we cannot but note the inconsistency in the use of quotation marks and italics to single out particular words or expressions. However, as this procedure follows no discernible pattern, it is unlikely to be significant and perhaps 
awareness of the discrepancy between the discourse language (Spanish) and the story language (here presumably English). Although on the surface, in all these examples the critics appear to make reference to a specific linguistic expression, what their reflections actually do is highlight the occasional inadequacy and fallibility of language, generically understood.

The academics' linguistic awareness and sensitivity finds its equivalent in the narrator's tendency to single out individual words used by the characters in the course of a conversation, to either give the gist of a speech event or raise doubts about the actual use of words in a given situation. In both types of intervention, the presumed literalness of language is, again, decoupled from any specific language. A prominent example of the first type is a long phone conversation between Frenchman Pelletier and Spaniard Espinoza, in which they exchange impressions about their shared lover, Norton. Rather than offering a verbatim report of the conversation, the narrator lists some of the words used by the two friends - presumably representing the essence of the conversation - indicating in each case the frequency with which they appeared in the course of the phone call:

Los veinte minutos iniciales tuvieron un tono trágico en donde la palabra destino se empleó diez veces y la palabra amistad veinticuatro. El nombre de Liz Norton se pronunció cincuenta veces, nueve de ellas en vano. La palabra París se dijo en siete ocasiones. Madrid, en ocho. La palabra amor se pronunció dos veces, una cada uno. La palabra horror se pronunció en seis ocasiones y la palabra felicidad en una (la empleó Espinoza). La palabra resolución se dijo en doce ocasiones. La palabra solipsismo en siete. La palabra eufemismo en diez. La palabra categoría, en singular y en plural, en nueve. La palabra estructuralismo en una (Pelletier). (61-62)

By highlighting only selected elements of the conversation, the narrator maintains full control of the narrative, offering his own interpretation of the speech event, viewed with the same ironic detachment found throughout 'La parte de los críticos'. Not only is it clear that, with the exception of the proper names, none of these words was actually spoken in the imaginary phone conversation in the form in which they appear in Bolaño's novel. Strictly speaking, even the name of the French capital varies according to the language used: París (Spanish) - Paris (with identical spelling but different pronunciation in English, German and French) - Parigi (Italian). But more importantly, the insistence on isolating individual words again goes hand in hand with the refusal to consider language use in relation to language choice, i.e. to a particular language.

A second example illustrates how the narrator calls into question the wording of a speech event rendered summarily, suggesting that his straightforward report of events represents the conversation more faithfully than any of several alternative phrasings of the original dialogue: 'Norton le contó [a Espinoza] que era amante de Pelletier, aunque no fue ésa la palabra que empleó sino otra mucho más ambigua, como amistad, o tal vez dijo que mantenía un ligue, o algo

best understood as a result of insufficient copyediting of the book manuscript prior to publication. 
parecido' (52). The passage leaves no doubt that, in terms of referential clarity, the narrator's brief summary of the speech event is shown to be superior to the original wording. However, the fact that Bolaño insists on juxtaposing the narrator's version with the ambiguous term used by Norton, whose exact wording - to complicate things further - seems to elude his grasp, not only highlights the narrator's determination to impose his authority but once again flags up both the fallibility of verbal communication and the elusiveness of language in its real-life context.

As we have seen, Bolaño's homogenizing intervention in the assumed linguistic raw material presumes a translation of all speech acts performed in languages other than Spanish - which are the vast majority - into a single discourse language. However, in a movement pointing in the opposite direction, Bolaño insists on drawing attention to the pitfalls of linguistic communication and the fallibility of verbal language use in general, thereby further shifting the focus from interlingual to intralingual communication. It becomes clear that within the fictional world of 2666, speech events at the story level are often unstable and fuzzy referents insofar as the authoritative version offered by the narrator cannot reliably be linked to a specific wording on the characters' part, which at times eludes the narrator's grasp altogether. In that universe, a single stable meaning can take linguistic shape in a variety of unstable ways ('Espinoza [...] pensaba lo mismo, aunque con otras palabras' (117)). Put in more abstract terms, the link between the linguistic sign (the speech event as rendered by the narrator) and its referent (the speech event as occurred in the story) is broken. Rather than pretending to mimetically transcribe speech events, Bolaño limits himself to vouching for the meaning of specific instances of language use (the signified, in Saussurrean terms), assigning them a different linguistic signifier. While this procedure applies, at least to some degree, to all linguistic representations of direct discourse, literary or otherwise, readers are not generally made aware of it. What draws the attention here is Bolaño's insistence on juxtaposing the narrator's version with incongruous or ambiguous elements from the original speech event. This textual strategy openly undermines the idea of a quasi-mimetic representation of direct discourse, highlighting the narrator's power over the diegetic world. Ultimately, this anti-mimetic stance lays open the very process of fiction-making, destroying the illusion of a raw reality that precedes narrative representation. Both at the microlevel and at the macrolevel, fiction - such seems to be the suggestion - starts with a narrative proposition, which triggers the search for a linguistic vehicle capable of communicating that proposition.

The narrator's attitude towards languages other than Spanish and the corresponding disregard for the challenges involved in interlingual communication within the Eurotopian communicative space can be linked to Bolaño's preference for literature written in Spanish. Although, as noted above, in his articles and speeches he comments on writers from a range of different cultural and linguistic backgrounds, Bolaño does not generally draw attention to the 
language in which they write. Just as the characters of his novels appear to communicate by means of a generic language, Bolaño discusses his readings simply as literature. On both levels, language choice seems to be of little or no consequence. Judging by Bolaño's reading pattern, as documented by his critical writing, he had no particular inclination towards the study of foreign languages. At some point he even declared openly, 'No sé leer inglés' (Bolaño 2004b: 40). To satisfy his thirst for reading matter, he therefore depended heavily on Spanishlanguage translations. In what is probably Bolaño's only sustained reflection on literary translation, published under the title 'La traducción es un yunque' in his weekly newspaper column 'Entre paréntesis' six months before his death, he proposed translation as the touchstone for 'obras maestras absolutas' (2004b: 223). According to Bolaño, if - and only if - readers across time and linguistic barriers feel consistently drawn to a text in translation, are we dealing with an 'absolute masterpiece', that is, a work of art that is 'patrimonio de todos los hombres' (223). Interestingly, in his discussion Bolaño is not in the least concerned about a translation's quality. On the contrary, he believes that the true test for a universal masterpiece is that its magic ('magia' (223)) unfolds even when a translation has severely mutilated the original work. This lack of interest in how literature travels across boundaries, both cultural and linguistic, chimes in with 2666's indifference towards the implications of language choice.

It seems plausible to link this essentialist attitude to Bolaño's own experience as an avid expert reader capable of spotting literary merit through the linguistic mist of even the least competent of translations. More specifically, however, it may have been the encounter with Wittgenstein's work that guided Bolaño's intuition in these matters. Although I am not aware of any sustained reflection on the Austrian-British philosopher in Bolaño's work, in the essays and articles reproduced in Entre paréntesis (2004b), he mentions Wittgenstein several times, always in contexts that suggest admiration and familiarity with his work. Both the Tractatus logico-philosophicus (1921) and the Philosophical Investigations (manuscripts published posthumously in 1953) are explicitly referred to; the former, in Bolaño's last interview, as one of the books that have had a major impact on his life (2006: 70).

It is not immediately obvious why Wittgenstein's Tractatus would have appealed to Bolaño. Perhaps it was the text's aphoristic concision and rigid structure as much as its uniqueness and obscure meaning, which even Bertrand Russell, as Wittgenstein insisted, had misunderstood (Ishiguro 2001: 28). Whatever Bolaño's understanding of Wittgenstein's claims regarding language may have been, it is striking (although unsurprising, given Wittgenstein's focus on the logic of language) how little concern the Tractatus shows for the specific differences between real-world languages and the issues arising from language contact and translation. In fact, in Wittgenstein's consideration of logically perfect languages, translation is seen as a foolproof mechanical process governed by rules. A language's seamless translatability is even taken as an essential characteristic of its 'correctness': 'Las definiciones son reglas para traducir una lengua 
a otra. Cada simbolismo correcto debe ser traducible a cada uno de los otros de acuerdo con tales reglas. Esto es lo que todos tienen en común' (Wittgenstein 1973: §3.343; italics in the original). ${ }^{12}$ The stress on the commonality between languages and the assumed transparency of translation is reinforced in another passage of the Tractatus. Here Wittgenstein takes for granted the identity of meaning between corresponding words of different languages, implying their perfect translatability: 'Si yo conozco el significado de una palabra inglesa y de la correspondiente palabra alemana, es imposible que no sepa que tienen el mismo significado, es imposible que no sepa traducir la una en la otra' (Wittgenstein 1973: §4.243).

This simplistic view of language difference and translation, which perhaps reflects the young Wittgenstein's lack of interest in real-world communication, is remarkably similar to that shown by Bolaño in 2666. Although both authors acknowledge the existence of linguistic diversity and translation, they do not perceive either as problematic; their writing focuses instead on the possibilities and limits of language, understood generically. This brief discussion of passages from the Tractatus suggests that Bolaño shared with Wittgenstein certain basic interests and blind spots, the consequences of which can be observed with particular clarity in 'La parte de los críticos'.

In conclusion, while the linguistic flatness of 2666 may well be one factor that allows us to understand the ease with which the work has travelled from Spanish into other languages, ${ }^{13}$ dismissing this textual characteristic as a marketing ploy or a weakness of Bolaño's writing is overlooking the programmatic implications of the text's complex narrative make-up. The narrator of 'La parte de los críticos' shares with the protagonists a linguistic awareness which for the most part conceives language not in terms of any particular tongue but generically as a medium of communication, whose fallibility the novel's first part explores in a number of ways, often with comic effect. The narrator can be seen as a kind of master translator who guarantees a level playing field for all main characters, regardless of their linguistic background. His translation is perfect insomuch as it obviates the pitfalls of communication across languages and allows the four academics to interact without difficulties. This communicative Eurotopia, however, does not extend beyond the four professional linguists who move with great ease within the confines of Western European mainstream culture. In contrast to 'modernist responses to a perceived “crisis" of language' (Taylor-Batty 2013: 37; see also ch. 2), Bolaño sets an ideal of perfect translatability made possible by way of literature. In place of the myriad contemporary problems surrounding language contact and translation, in place of the Babel story of mutual incomprehension, he proposes the Eurotopian communicative

12 For my argument, I draw on the Spanish translation of the Tractatus, as this is the text Bolaño would have been familiar with.

13 To date, the novel has been translated into more than 15 languages. In addition to the European languages referenced in the book itself, these include Bosnian, Chinese, Czech, Danish, Hebrew, Japanese, Korean, Polish, Slovenian, Swedish and Turkish. 
space. While this programme is sustained by 2666 as a whole, its implementation is particularly salient in 'La parte de los críticos'. The most perfect example of the proposed interlingual transparency, however, is the very title of the novel, 2666, whose Arabic numerals altogether remove the need for translation.

This article was published open access under a CC BY license. https://creativecommons.org/licenses/by/4.0/

\section{Works Cited}

Bolaño, Roberto, 1996. La literatura nazi en América (Barcelona: Seix Barral).

,- 1998. Los detectives salvajes (Barcelona: Anagrama).

-, 2004a. 2666 (Barcelona: Anagrama).

-, 2004b. Entre paréntesis. Ensayos, artículos y discursos (1998-2003), ed. Ignacio Echevarría (Barcelona: Anagrama).

-, 2006. Bolaño por sí mismo. Entrevistas escogidas, selección y edición de Andrés Braithwaite (Santiago de Chile: Ediciones Universidad Diego Portales).

—, 2008. 2666, traduit de l'espagnol (Chili) par Robert Amutio (Paris: Gallimard).

-, 2010. El Tercer Reich (Barcelona: Anagrama).

Cercas, Javier, 2007. 'Print the Legend!', El País, 14 April. Available at: <http://elpais.com/ diario/2007/04/14/babelia/1176507550_850215.html> [accessed 1 December 2017].

Cuevas Guerrero, Carlos, 2006. 'Escritura e hipérbole. Lectura de 2666 de Roberto Bolaño', Espéculo. Revista de Estudios Literarios, 12.34. Available at: <http://www.ucm.es/info/especulo/ numero34/hiperbol.html> [accessed 1 December 2017].

Deckard, Sharae, 2012. 'Peripheral Realism, Millennial Capitalism, and Roberto Bolaño's 2666', Modern Language Quarterly, 73.3: 351-72.

Dwyer, Tessa, 2005. 'Universally Speaking. Lost in Translation and Polyglot Cinema', Linguistica Antverpensia, 4: 295-310.

Echevarría, Ignacio, 2004. 'Nota a la primera edición', in 2666 by Roberto Bolaño (Barcelona: Anagrama), pp. 1121-25.

Ercolino, Stefano, 2014. The Maximalist Novel. From Thomas Pynchon's Gravity’s Rainbow to Roberto Bolaño's 2666 (New York: Bloomsbury).

European Commission, 2012. Special Eurobarometer, 386 (Europeans and their Languages). (Brussels: European Commission, Directorate-General for Communication), June. Available at: <http://ec.europa.eu/public_opinion/archives/ebs/ebs_386_en.pdf> [accessed 1 December 2017].

Ishiguro, Hidé, 2001. 'The So-called Picture Theory. Language and the World in Tractatus LogicoPhilosophicus', in Wittgenstein: A Critical Reader, ed. Hans-Johann Glock (Oxford: Blackwell), pp. 26-46.

Jaramillo, Darío, 2007. 'Mago de un solo truco', El País, 14 April. Available at: <http://elpais.com/ diario/2007/04/14/babelia/1176507557_850215.html> [accessed 1 December 2017].

Lainck, Arndt, 2014. Las figuras del mal en 2666 de Roberto Bolaño (Berlin: Lit).

Levinson, Brett, 2009. 'Case Closed: Madness and Dissociation in 2666', Journal of Latin American Cultural Studies, 18.2-3: 177-91.

Medina, Alberto, 2009. 'Arts of Homelessness. Roberto Bolaño or the Commodification of Exile', Novel: A Forum on Fiction, 42.3: 546-54.

Meneses, Juan, 2014. “'Like in the Gringo Movies”. Translatorese and the Global in Roberto Bolaño's 2666', in The Paradox of Authenticity in a Globalized World, ed. Russell Cobb (New York: Palgrave Macmillan), pp. 175-85.

Patterson, Annabel, 2014. 'Roberto Bolaño, 2666. Apocalypse in a Border Town', in The International Novel (New Haven, CT: Yale University Press), pp. 205-21.

Pollack, Sarah, 2013. 'After Bolaño. Rethinking the Politics of Latin American Literature in Translation', PMLA, 128.3: 660-67. 
Pope, Randolph D., 2011. 'A Writer for a Globalized Age. Roberto Bolaño and 2666', in Old Margins and New Centers. The European Literary Heritage in an Age of Globalization, ed. Marc Maufort and Caroline De Wagter (Brussels: P.I.E. Peter Lang), pp. 157-66.

Rodríguez de Arce, Ignacio, 2006. 'Una primera aproximación a 2666 de Roberto Bolaño', in Dal Mediterraneo L'America. Storia, Religione, Cultura, ed. Clara Camplani and Patrizia Spinato Bruschi (Rome: Bulzoni), pp. 173-211.

Sternberg, Meir, 1981. 'Polylingualism as Reality and Translation as Mimesis', Poetics Today, 2.4: 221-39.

Taylor-Batty, Juliette, 2013. Multilingualism in Modernist Fiction (Basingstoke, UK: Palgrave Macmillan).

Wittgenstein, Ludwig, 1953. Philosophical Investigations, trans. G. E. M. Anscombe (Oxford: Basil Blackwell).

-, 1973. Tractatus logico-philosophicus, trans. Enrique Tierno Galván (Madrid: Alianza).

Zurita, Raúl, 2008. '2666 de Roberto Bolaño. Un asunto irresuelto', Carajo 9. [Online - reproduced in Proyecto Patrimonio. Archivo de autores. Escritores y poetas en español.] Available at: $<$ http://www.letras.mysite.com/rb100208.html> [accessed 1 December 2017]. 
